\title{
LAND CREATIONS AND FARMING SYSTEM TO INCREASE OF RICE PRODUCTIVITY AND FARMER'S INCOME (CASE STUDY IN BATANG TAMPO IRRIGATION SYSTEM - LINTAU BUO)
}

\author{
Ayendra Asmuti* and Agita Tjandra \\ Lacturer of Andalas University \\ Email: Ayendraarda@gmail.com
}

\begin{abstract}
It is estimated that around 95 percent of national rice production is supplied from paddy fields, so the paddy fields is very strategic in national food securities. Therefore, the potential carrying capacity and productivity of rice fields must be maintained and developed. But on the contrary the productivity of paddy fields in Sub Das Tampo, Lintau Buo Utara, Tanah Datar District, West Sumatra, there is an indication of a decrease in paddy productivity in the last 10 years (Agita and Ayendra 2018). Decreased paddy productivity is indicated as a result of 1.) Drainage or nutrient deficit due to harvest carried out more than what is given through fertilization or addition of nutrients from irrigation water, 2). Excess or lack of certain nutrients due to unbalanced fertilization, 3). Decreased of soil organic content in the land and 4). Decrease in the quality of rice field management, especially: a). the use of inorganic fertilizers which causes low organic matter content and soil texture becomes porous quench, so it is less able to hold water, b). use of rotary plow in tillage for a long time which causes the processing layer and the depth of the root zone to become shallower ( into 10-15 cm), c). less intense of crop maintenance. This research was carried out by creating of soil tillage from $10-15 \mathrm{~cm}$ to $20-25 \mathrm{~cm}$ using a plow and increasing of organic matter by adding manure of 50 tons / ha (5\% soil tillage zone ) to the rice fields in the Farmers Group of Tanjung Mutiara in Tampo Irrigation System, Nagari Lubuk Jantan, Kecamatan Lintau Buo Utara. The results of the study showed an increase in land productivity from an average of 3.2 tons / ha to 4.6 tons / ha and increase farmers' income by Rp 1.200.000 / ha.
\end{abstract}

Key words : land creation, soil tillage, productivity

(C) 2020 Asmuti and Tjandra

\section{INTRODUCTION}

The Government through the Ministry of Agriculture has launched an Increase in National Rice Production (P2BN). This program focuses on empowerment to increase national rice production by an average of 5 percent per year. It is estimated that around 95 percent of national rice production is supplied from paddy fields, so the position of paddy fields is very strategic in meeting national needs. Therefore, the potential, carrying capacity and productivity of rice fields must be maintained and developed. But instead the productivity of rice fields can decrease as a result of: 1). Drain or nutrient deficit due to harvest carried more than given through fertilization or addition of irrigation water, 2). Excess or lack of certain nutrients due to unbalanced fertilization, 3). Decreased soil organic matter and 4). Decreasing the quality of rice field management.

An area that is indicated to have decreased productivity in paddy fields is in the Batang Tampo Irrigation Area, Kecamatan Lintau Buo Utara and Kecamatan Lintau Buo. Under normal conditions, the rice fields in Batang Tampo have a planting intensity of 5 times in two years and some other times 2 
times a year. The results of Agita and Asmuti's research (20018) showed a level of cropping intensity of 2 to 2.5 of $87 \%$ and more than 2.5 of $3 \%$. This means that $90 \%$ or more of the rice fields are planted more than twice a year. This indicator shows that irrigation services are quite good. But in terms of production there are still low productivity levels of rice fields which are below 5 tons per hectare or below the level of production that might be achieved in this area (more than 6.5 tons per hectare). Some indications that cause the low production that can be achieved include: a). Because of mismanagement and over explotation (high crop inten -sity) so that paddy fields are also experiencing fertility degradation or decreased of productivity. b). The shallow depth of the topsoil (10-15 cm). Agita and Asmuti (2018) found that the shallowing of the topsoil from 25 - 30 to $10-15 \mathrm{~cm}$ in the last 25 to 30 years caused the non-optimal layer of rice to grow the roots of rice plants and the lack of water reserves, c). Lack of organic material due to rice fields is fertilized with anorganic fertilizers which causes the low content of organic matter and soil texture to become porous, thus reducing the ability to retain water, $d$ ). The use of plate plow in tillage (Disk plow or rotary plow) in a long time which causes the shallow of soil cultivation e). Plant maintenance is less intense due to many farmers who live not in the agricultural area. Many farmers give fertilizer without calculating the type and how much to give. Usually the type of fertilizer and the amount of fertilizer given is based on old recommendations, f). irrigation water management which is not optimal according to the amount and time of water supply.

In addition to the above conditions, in terms of area management, most of the paddy rice farmer $(85 \%)$ only manage less than 0.4 ha (Agita and Asmuti, 2018) so that it is difficult to expect an increase in farmers' welfare due to the limited land that is managed. The time spent by farmers to work in the paddy business is on average only around 2 to 3 hours per day so that farmers still have working hours that have not been utilized.

From the description of this problem, several questions arise that need to be answered through a study in sequence as follows:

1. How to increase the productivity of rice by optimizing the factors of production that influence to increase the productivity of rice field.

2. How to increase farmers' income by improving the management system of paddy farming with limited land area.

Precission farming for paddy rice farming can be interpreted as an effort to increase productivity of paddy fields by providing measurable agricultural inputs in accordance with the needs of paddy fields and paddy crops with the right type, amount and time to get maximum production results in accordance with the potential of paddy fields. . While farming business management is how farmers manage their businesses with the potential of paddy fields and nature and their environment to increase their income and welfare. One way to increase the income of paddy farmers is by increasing the capital of their business land or increasing the scale of the business scale in the framework of achieving business economies of scale.

This study aims to optimize all factors of land, water and farm management to increase land productivity and increase farmers' income. Farming activities are carried out in the field using the principles of precission farming by optimizing all existing production factors such as: 1) optimal tillage, 2) use of organic matter to achieve composition optimal soil texture, 3) optimal irrigation water supply, 4) analysis of fertilizer requirements 4). Control of weeds, pests and diseases.

\section{MATERIAL AND METHODE}

The study was conducted in a rice field located in the Kelompok Tani Tanjung Mutiara ( Farmer Group ), Jorong Kamboja, Nagari 
Lubuk Jantan, Kecamatan Lintau Buo Utara, Kabupaten Tanah Datar, West Sumatra Province, May to October 2019 ( rice planting season).

Land management tools such as singkal plow, rotary plow, hoe, rake and tick, tape measure to measure land area, Measuring iron to measure into the processing layer and into the puddle water in the fields. ring soil samples to measure soil porosity and scales capacity of $100 \mathrm{~kg}$ for weighing fertilizer.

Manure (chicken or beef), Rice seeds, inorganic fertilizers: Urea, TSP, material for controlling pests and plant diseases (inorganic or organic pesticides).

\section{Work Procedures and Steps:}

a). Before planting

-. Measure the area of the land with a tape measure and measure the depth of the processing layer with an iron meter to calculate the volume of the tillage layer.

-. Take a soil sample using a sample ring and calculate soil volume, soil density, porosity and soil moisture content before the study, when planting and at the end of the study after harvest.

-. Soil volume is needed to determine the soil density and how much manure is needed to get the ideal soil composition for growing rice. The amount of organic matter added is the amount that will arrange the composition of organic matter to be $5 \%$ of the soil structure according to soil volume. Where the ideal soil composition is $45 \%$ mineral soil material, $5 \%$ organic matter, $25 \%$ water and $25 \%$ air.

-. Soil density needs to be known to know the volume of soil that makes up the tillage and calculate the amount of organic fertilizer.

. The porosity of the soil must be known and needed to calculate the amount of irrigation water supply for land saturation before tillage, during planting, during plant growth and maintenance.

- Weigh and calculate the volume of manure to find out the density of manure.
-. Before the soil starts, make the seedbed in a separate place.

-. Spread manure according to the calculation (b) above.

-. Fill the soil with water according to calculation (b), above.

-. Let the soil be sprinkled with fertilizer and saturated with water within a few days until of organic fertilizer aroma disappears as an indicator of manure has matured.

b). Seeding rice seeds

The need for seeds for 1 area of paddy rice is $20-25 \mathrm{~kg}$. Land area for nursery is $4 \%$ of the estate area or around $400 \mathrm{~m} 2$ per hectare of plantation. The soil that is used for rice seedbed seedlings is usually cultivated first. The soil is in a hoe or plowed and left in a shredded condition for at least 2 days, then allowed to dry for up to 7 days so that the grain in the soil grows. The seeds to be sown must be soaked in advance for about $2 \times 24$ hours. The nursery is carried out 25 days before planting, the nursery is carried out on the same land or adjacent to the rice fields that will be planted, this is done so that the seeds that are ready to be moved can stay fresh.

Seeds that have been soaked and have germinated are sown carefully and evenly so that the growing seeds do not overlap. Seedlings that are sown do not have to be buried in the ground because they can cause sprouts to be infected with pathogens which can cause sprouts to rot. During the nursery, fertilizer application is needed about a week after the seed is planted (sown). Fertilazer used are $2.5 \mathrm{~kg}$ Urea, $2.5 \mathrm{~kg} \mathrm{SP} 36$, and $1 \mathrm{~kg} \mathrm{KCl}$.

c). Tillage

-. Rice field plow with singkal plow in accordance with the designed depth $(20 \mathrm{~cm})$.

-. Crush the ground to become smoother by using a rotary plow.

-. Blend the soil using a ground brush and spread it evenly.

-. Leave the soil for two days to stabilize the surface of the land with the condition of a flat 
surface and saturated with water but not flooded.

d). Planting

Planting is the process of transferring seedlings from a nursery to the land as a place to grow plants. Planting is carried out when the seed takes 15-21 days with 2 to 3 seedlings per hole (BBPPP, 2009). Seedlings used are seeds that have the same physiology (marked by the same number of leaves and height). The spacing and planting system used were the Legowo row $30 \times 15 \times 30 \mathrm{~cm}$, the Legowo row 5: 1 . Seedlings are planted in $1-2 \mathrm{~cm}$ deep. The remaining seeds that have been pulled out are placed on the edge of the map, to be used in replanting. Replanting is done 7 days after planting with seeds of the same variety and age. After being planted, the irrigation water is left messed up (1-3 cm) for 21 days.

e). Plant maintenance

-. Fertilization

The type, quantity and time of fertilization are adjusted to the needs of the plant by taking into account the condition of the plant, the age and growth of the plant, the type of fertilizer as well as the water conditions in the fields and irrigation water conditions.
-. Water management rovision of plant water during tillage, planting and plant growth is monitored in real time. Basically, theoretically rice plants do not require standing water but the amount of water needed for rice plants is relatively greater than other types of plants because of the shape of plants that have a large total surface area of leaves. Therefore, efforts are made to make the inundation level relatively low or not even inundated to enrich oxygen in the soil but still in a field of available or available capacity.

-. Control of weeds, pests and plant diseases

Weed, pest and plant disease controls are carried out according to conditions in the field. In the initial stages, irrigation water is needed until the number of leaves of the rice plant is sufficient to cover the surface of the land to suppress weed growth. The challenge of pests in this research area at the beginning of plant growth is the golden snail pest that attacks young rice plants. Gold snail pest is controlled by reducing inundation. In the next period weeds are overcome by weeding and using other facilities in accordance with the level of attack on rice plants.

Observation, Measurement and Calculation of cost analysis

\begin{tabular}{llccc}
\hline No. & \multicolumn{1}{c}{ Parameters } & Before planting & After planting & After harvesting \\
\hline 1. & Depth of tillage & $20-25 \mathrm{~cm}$ & - & - \\
2. & Specific gravity & 1,25 & - & - \\
3. & Soil density & - & - & - \\
4. & Specific gravity of manure & $0,40 \mathrm{~kg} / 1$ & - & - \\
5. & Porosity of the Soil & $0,46 \%$ & - & - \\
6. & Use of seeds & $26 \mathrm{~kg} / \mathrm{ha}$ & - & - \\
7. & Use of fertilizer (type and & Manure 50 ton/ha Urea 100 and Ponska $100 \mathrm{~kg} / \mathrm{ha}$ \\
& amount) & & - & - \\
8. & The use of pest and plant disease & - & - & - \\
9. & Control substances & - & 32 & - \\
10. & Yhe number of stems in a clump & - & - & - \\
11. & Cost analysis & - & - & \\
\hline
\end{tabular}

The analysis is carried out by comparing the farming carried out with the farming system with two adjacent rice fields. 


\section{RESULTS AND DISCUSSION Research Implementation}

a). Before planting

-. Measurement results: 2,600 $\mathrm{m} 2$ of paddy fields, with a depth of 10-17 cm ( before tillage )

-. The initial water content is $47 \%$, the initial soil specific gravity is $1.25 \mathrm{~kg} / 1$, the specific gravity of cow manure is $0.4 \mathrm{~kg} / 1$ and chicken manure is $0.46 \mathrm{~kg} / 1$.

-. To increase the volume of soil organic layer by $5 \%$ at a depth of $25 \mathrm{~cm}$ requires an organic layer of $1.25 \mathrm{~cm}$, or equivalent to the volume of cow manure by $1.25 \mathrm{~cm} \mathrm{x} 10,000 \mathrm{~m} 2$ or 125 $\mathrm{m} 3$, or weighing $125 \mathrm{~m} 3 /$ ha $\times 400 \mathrm{~kg} / \mathrm{m} 3=$ $50,000 \mathrm{~kg} / \mathrm{ha}$. The average weight of 1 sack of cow dung is $35 \mathrm{~kg}$. Thus for an area of 2600 m2 376 sacks of cow manure are needed.

-. Seed nursery area 4\% x $2600 \mathrm{~m} 2=104 \mathrm{~m} 2$

-. Manure is spread before the soil is cultivated or 2 weeks before planting.

-. Cover the soil with water before planting it for the first time.

b). Seeding rice seeds

Seed needs for an area of $7 \mathrm{~kg}$. The soil is in a hoe and plowed a week before processing the whole soil and left in a condition of shredding for at least 2 days, then allowed to dry for up to 7 days so that the grain in the soil grows. Seeds that will be sown soaked in advance for about 2 x 24 hours. The nursery is carried out 25 days before planting, the nursery is done on the same land. Seeds that have been soaked and have germinated are sown carefully and evenly so that the growing seeds do not overlap. Fertilizing is done a week after the seeds are planted (sown). Anorganic fertelizer needs are $2.5 \mathrm{~kg}$ Urea, $2.5 \mathrm{~kg} \mathrm{SP36}$, and $1 \mathrm{~kg} \mathrm{KCl}$.

c). Tillage

-. Rice field plow with singkal plow in accordance with the depth designed $25 \mathrm{~cm}$

-. Crush the ground to become smoother by using a rotary plow.
-. Blend the soil using a ground brush and spread it evenly.

-. Leave the soil for two days to stabilize the surface of the land with the condition of a flat surface and saturated with water but not flooded.

d). Planting

Planting is carried out during the seeds period of 19 days with 2 to 3 seedlings per hole (BBPPP, 2013). Seedlings used are seeds that have the same physiology (marked by the same number of leaves and height). Planting distance and planting system used were Legowo row 30 x 15 x $30 \mathrm{~cm}$, Legowo row 5: 1. Seedlings are planted in 1-2 cm deep. Replanting is done 7 days after planting with seeds of the same variety and age. After being planted, the irrigation water is left messed up (1-3 cm) for 21 days.

\section{e). Plant maintenance}

\section{-. Fertilization}

Type, quantity and time of fertilization are given half of the usual amount recommended because of manure or $25 \mathrm{~kg}$ of urea and $25 \mathrm{~kg}$ of TSP when the plant is 4 weeks old.

Provision of plant water during tillage, planting and plant growth is monitored in real time. Basically, theoretically rice plants do not require standing water but the amount of water needed for rice plants is relatively greater than other types of plants because of the shape of plants that have a large total surface area of leaves. Therefore, efforts made to make the inundation level relatively low or not even inundated to enrich oxygen in the soil, but still in a field of available capacity -- Control of weeds, pests and plant diseases

Weed, pest and plant disease controls are carried out according to conditions in the field. In the initial stages, irrigation puddles are not needed to reduce the conch pest attack. By regulating inundation for this land no weeding is needed. 
Nutrient Content of Soil and Dried Fertilizer Before and After Adding Manure

\begin{tabular}{llrrrr}
\hline No. & Element of analysis & \multicolumn{1}{c}{ Soil I } & Manure & \multicolumn{1}{c}{ Soil II } & \multicolumn{1}{c}{ Soil III } \\
\hline 1. & N-total (\%) & 0,28 & 1,27 & 0,28 & 0,33 \\
2. & P-available (ppm) & 80,55 & 80,5 & 80,50 & 16,27 \\
3. & K,dd (me/100 gr) & 0,44 & 1,31 & 80,50 & 0,42 \\
4. & C-organic (\%) & 5,85 & 13,6 & 0,43 & 2,45 \\
5. & B-organic & 10,09 & 23,5 & 10,89 & 5,37 \\
6. & C/N & 20,30 & 13,2 & 20,39 & 9,32 \\
\hline
\end{tabular}

The application of organic fertilizer two weeks before planting does not provide any changes in nutrients in the soil, especially
$\mathrm{N}, \mathrm{P}, \mathrm{K}, \mathrm{C}$ organic and organic B (Soil I and Soil II), but it changes less after harvest (Soil III).

\section{Observation and Measurement}

\begin{tabular}{ll}
\hline No. & Parameters \\
\hline 1. & Depth of tillage \\
2. & Specific gravity \\
3. & Soil density \\
4. & Specific gravity of manure \\
5. & Density of manure \\
6. & Porosity of the Soil \\
7. & Ammount of water supply \\
8. & Use of seeds \\
9. & Use of fertilizer (type and \\
10. & The use of pest and plant disease \\
11. & Thentrol substances \\
12. & Yields
\end{tabular}

Before planting After planting After harvesting $20-25 \mathrm{~cm}$

$1,25 \mathrm{~kg} / 1$

$1,35 \mathrm{~kg} / 1$

$0,40 \mathrm{~kg} / 1$

$47 \%$

$7 \mathrm{~kg} / 2600 \mathrm{~m}^{2}$

Urea $25 \mathrm{~kg}$ and Ponska $25 \mathrm{~kg}$

\section{Calculation of cost analysis}

The analysis is carried out by comparing the farming carried out with the farming system with two adjacent rice fields. The results of comparison with the fields around the study site show productivity research sites are 4.5 tons / ha, while the rice fields next to them are 3.2 tons / ha, or worth $1,300 \mathrm{~kg} \times \mathrm{Rp} 5,500 / \mathrm{kg}=\mathrm{Rp} 7,150,000 / \mathrm{ha}$. However, land management costs and higher fertilizer costs at the study site were Rp $5,950,000 /$ ha. By applying farming patterns in the research location it is able to increase farmers' income worth IDR 1,200,000 / ha. The value of increasing productivity is expected to be greater in the next planting period after the

$-$

Average 32 stems

study because there is still residual manure that is in the research location that has not been utilized and with the improvement of the condition of the paddy soil.

\section{CONCLUSIONS}

AND

\section{RECOMMENDATIONS}

1. The creation of land, water and farming in the context of "Precission Farming" has been proven increase the productivity of paddy fields and increase farmers' income and can be applied in limited conditions adapted to existing land conditions

2. It takes an increase in human resources for the application of precission farming in optimizing to increase of production. 
3. More thorough preparation is needed in all aspects for the application of precission farming.

4. It is recommended that wider farm management be used to optimize the application of land creating of water and farming to increase farmers' income more optimally.

\section{DAFTAR PUSTAKA}

Agita dan Asmuti 2018. Pemetaan Kapasitas Pelayanan Irigasi Dengan Menggunakan Remote Sensing. Daerah Irigasi Batang Tampo, Lintau Buo. Penelitian Dana Dipa Fakultas Teknologi Pertanian Universitas Andalas.

Asmuti, Ayendra. 1995, Analisis Keragaan Teknis dan Ekonomi Beberapa Taraf
Teknis Irigasi Gravitasi Padi Sawah (Studi Kasus Irigasi di Sumatera Barat).Tesis S2. IPB Bogor (Tidak dipublikasikan)

Badan Ketahanan Pangan Dan Penyuluhan Pertanian Bekerjasama Dengan Badan Pengkajian dan Penerapan Teknologi Pertanian NAD. 2009. Budidaya Tanaman Padi.

Asmuti, Ayendra. 1995, Analisis Keragaan Teknis dan Ekonomi Beberapa Taraf Teknis Irigasi Gravitasi Padi Sawah (Studi Kasus Irigasi di Sumatera Barat).Tesis S2. IPB Bogor (Tidak dipublikasikan ). 